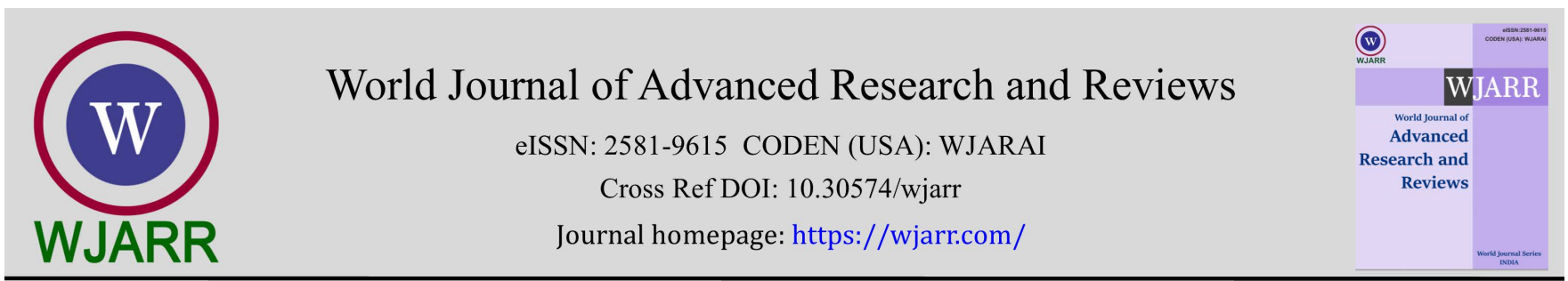

(RESEARCH ARTiClE)

Check for updates

\title{
Agroforestry practices and food security in the mount Bamboutos landscape, Western Highlands of Cameroon
}

\author{
Njukeng Jetro Nkengafac $1{ }^{*}{ }^{*}$, Louis Nkembi ${ }^{2}$, Ngulefack Ernest Forghab ${ }^{2}$ and Asabaimbi Deh Nji 2 \\ ${ }^{1}$ Institute of Agricultural Research for Development (IRAD), Ekona Research Centre, PMB 25 Buea, South West Region \\ Cameroon. \\ 2 Environment and Rural Development Foundation (ERuDeF), Civil Society Building, Co-Cathedral Road Molyko Buea, \\ South West Region Cameroon.
}

World Journal of Advanced Research and Reviews, 2021, 11(01), 203-211

Publication history: Received on 02 June 2021; revised on 19 July 2021; accepted on 22 July 2021

Article DOI: https://doi.org/10.30574/wjarr.2021.11.1.0311

\begin{abstract}
This study presents agroforestry practices by farmers in Mount Bamboutos, why they adopt agroforestry practices and main constraints towards adoption as well as the relationship between agroforestry practices and household food security. A purposive sampling technique was used to administer 195 questionnaires. Data collected were analyzed using both descriptive and inferential statistics. The demographic information analyzed showed that the majority of respondents were males (76\%) and all were literate with a majority using fuel wood as their main source of energy. The major agroforestry practices were, planting of fodder, fertilizer, fruit and timber trees, compost manure and farm yard manure preparation. The highest year of adoption of agroforestry practices was in 2019. Most (50\%) of the respondents adopted agroforestry practices for better crop yields. However, the main constraints to agroforestry adoption were lack of training, lack of seeds and much labour involved. Lack of training was the greatest constraint cited by respondents. $39 \%$ of the respondents were food secure and apart from compost manure practice that was negatively associated with food security, all the other agroforestry practices were positively associated with food security. Based on findings of this study, it is recommended that extension agents and other stakeholders should intensify efforts to educate and train more farmers on the practice and advantages of agroforestry. This will go a long way to increase adoption rate while ensuring food security.
\end{abstract}

Keywords: Agroforestry; Adoption; Constraints; Food security

\section{Introduction}

Agroforestry system is an integrated approach to solving land use problems. It is a form of sustainable land use system that combines tree with crop or animal husbandry simultaneously and sequentially. Agroforestry is the common farming practice that has been promoted throughout Africa due to its economic and social benefits [1].

Following the above definition, the main components of agroforestry systems are crops, trees and livestock. There are three key agroforestry systems namely agro-silviculture (trees and crops), silvopastoral (trees and livestock), and agrosilvopastoral (trees, crops and livestock) [2, 3, 4]. The practice of any agroforestry system ensures that farmlands remain productive for most of the time [5] and livelihoods are diversified [6,]. Some of the trees integrated in the farm fix nitrogen through root nodules as well as recycle nutrients and prevent wind and water erosion by means of their canopies and roots $[1,2]$. The green foliage from trimming/pruning or pollarding serves as green manure and improves soil nutrients [6]. Annual production of litter (leaves, twigs and flowers) also contributes to nutrient cycling [5].

\footnotetext{
* Corresponding author: Njukeng Jetro Nkengafac

Institute of Agricultural Research for Development (IRAD), Ekona Research Centre, PMB 25 Buea, South West Region Cameroon. 
Trees are very important as they provide soil and undergrowth production, wind speed reduction, moderation of extreme climatic conditions, and improvement of soil fertility $[2,7]$ as well as fruits, nuts, building materials and fodder $[3,5,8]$. Some agroforestry practices involving trees are, live fences, alley cropping, improved fallow, shelter belts, scattered trees on croplands and home gardens [9]. With the high plant diversity in these agroforestry farms [10], a wide spectrum of multiple-use plant products can be generated with relatively low labour, cash or other inputs [11]. In seasons of scarcity agroforestry systems with their diverse products available year-round, contribute towards food security [12].

Tree-based agroforestry land use practice is the most crucial for improving smallholder farmer's livelihoods [13]. With the expansion in the world population, the food problem has become increasingly severe, with the number of those malnourished reaching 3 billion [14]. Assessing the rate of population growth and rate of food production in Africa, Bishaw and Abdelkadir [15], found that during the period of 1993 to 2003 up till now, Africa's rate of population growth has been higher than the rate of food production. Despite the identification of food security as an important policy goal in Africa, too many African countries continue to be food insecure especially among the urban-poor [14]. This can be reversed through conscious integration of agroforestry practices into rural and urban development [16]. Agroforestry practices provide an additional food supply and cash income for the people.

The importance of agroforestry practices is based on the complexity of interactions between species that occur within agroforests, and their apparent sustainability over time in order to meet the people's needs in terms of food, fuel wood, livestock products (milk, eggs, meat) fodder, income and building materials. The primary emphasis of some practices like home gardens is food production for household consumption $[17,18]$.

Food insecurity is a major concern today in many parts of Cameroon which are fuelled by the increase in population density. High population density has put a lot of pressure on land as more of it is required for settlement [19]. This has led to land fragmentation, which has negatively affected food production, hence, resulting into food insecurity. Poor farming practices have led to decrease soil fertility and low crop yields [9]. Based on the MDG's goals for poverty alleviation, intensification and diversification of production strategies are of importance to meet the food and land requirement for the increased population. Land use practices thus have to be intensified to maximize food production on the small land available. Agroforestry has been identified as a means of providing all year-round access to food for rural households $[11,20]$ that helped smallholder farmers to support their families [21].

The Mount Bamboutos landscape is a biodiversity hotspot that is in constant threat of encroachment by local farmers. For over three years the Environment and Rural Development Foundation (ERuDeF), a Cameroon based nongovernmental organization together with her partners have been encouraging and training farmers on agroforestry for improved crop yields and to reduce encroachment. There is therefore need to access the contribution of these agroforestry practices to food security in this area. This study was meant to answer the following questions;

What type of Agroforestry technologies are practiced in the study area?

Which factors influence the adoption of agroforestry practices by households.

What is the relationship of these technologies to household food security?

The findings obtained from this study will be useful in redirecting, improving and strengthening the existing Agroforestry programmes in the Mount Bamboutous landscape and elsewhere in the country.

\section{Material and methods}

\subsection{Study area}

The Bamboutos Mountain is located between latitude $5^{\circ} 32^{\prime}$ and $5^{\circ} 51^{\prime}$ North of the equator and longitude, 956' and $1009^{\prime}$ east of the Greenwich Meridian and extends from an altitude of $2000 \mathrm{~m}$ to $2700 \mathrm{~m}$ above sea level. Mean maximum temperature is between $20-22^{\circ} \mathrm{C}$; mean minimum $13-14^{\circ} \mathrm{C}$. Rainfall varies from $1780-2290 \mathrm{~mm}$ per year. The weather conditions of the area favour crop production and animal rearing. The soils are characterized by low bulk density $(0.73 \mathrm{~g} / \mathrm{cm} 3)$ and a loamy texture [22].

\subsection{Data collection}

A purposive sampling design was used in this study. Eighteen villages within the Mount Bamboutos landscape were randomly selected out of 32 villages. A total of 195 questionnaires were administered to rural farmers in the 18 villages. Data gathered include: respondent's demographic attributes, source of farm land, farm size, source of energy, livelihood 
activities, adoption of agroforestry practices and constraints to its adoption as well as information of household food security.

\subsection{Statistical analysis}

The data collected from the respective respondents were edited to correct any missing information on the questionnaires and to ensure accurate results. Later, the data were coded with the aid of SPSS v23. Descriptive statistics and correlations were used to analyze the data collected. The descriptive statistics which include frequency distribution and percentage were used to summarize the respondents' socioeconomic characteristics. The household food insecurity access scale (HFIAS) was used to categorise households into four food security categories [23]. The Pearson correlation coefficient was used to determine the association between agroforestry practices and household food security. Based on the results, some deductions were made and appropriate recommendations for policy action provided.

\section{Results and discussion}

\subsection{Demographic and socioeconomic characteristics of respondents}

Table 1 Demographic and socioeconomic characteristics of respondents

\begin{tabular}{|c|c|c|c|}
\hline Variable & Description & Frequency & Percentage \\
\hline \multirow{2}{*}{ Sex } & Male & 148 & 76 \\
\hline & Female & 47 & 24 \\
\hline \multirow{4}{*}{ Age ranges (Years) } & $20-30$ & 33 & 17 \\
\hline & $31-50$ & 66 & 34 \\
\hline & $51-60$ & 53 & 27 \\
\hline & Above 60 & 43 & 22 \\
\hline \multirow{5}{*}{ Household size } & $1-5$ & 66 & 34 \\
\hline & $6-10$ & 92 & 47 \\
\hline & $11-15$ & 22 & 11 \\
\hline & $16-20$ & 5 & 3 \\
\hline & Above 20 & 10 & 5 \\
\hline \multirow{6}{*}{ Educational status } & Primary & 95 & 49 \\
\hline & Secondary & 71 & 36 \\
\hline & High school & 19 & 10 \\
\hline & Higher National diploma & 7 & 3.5 \\
\hline & Bachelors & 1 & 0.5 \\
\hline & Masters & 2 & 1 \\
\hline \multirow{5}{*}{ Main income source } & Crop farming & 158 & 81 \\
\hline & Livestock farming & 26 & 13 \\
\hline & Business & 3 & 1.5 \\
\hline & Government job & 5 & 2.5 \\
\hline & others & 3 & 1.5 \\
\hline \multirow{3}{*}{ Main source of energy } & Fuel wood & 188 & 96.5 \\
\hline & crop residues & 3 & 1.5 \\
\hline & others & 4 & 2 \\
\hline
\end{tabular}

Most of the respondents were male (76\%), with just 24\% female (Table 1). This implies that the majority of local residents engaging in agroforestry in the Mount Bamboutos landscape are males. There is gender disparity in agriculture in the region and this may explain the low number of females observed in this study. In Cameroon like some African countries most men have access to land and credit facilities whereas women do not. Generally, agroforestry practices are mostly done by men because of the cultural values and responsibilities of men in families. Women tend to 
be more interested in cultivating crops for food consumption rather than cultivating tree crops. This trend of gender disparity was observed in Rwanda [24]. Although women are traditionally important participants in both agricultural and forestry components of agroforestry production, they are frequently ignored in the design of agroforestry [25].

A majority (61\%) of the respondents were age between 31 and 60 years. This is an active age and it is interesting to note that $22 \%$ of the respondents were older than 50 years and $17 \%$ of age between 20 and 30 years. This is an indication that the young people are picking up the profession to replace the old people. Most (47\%) of the respondents` households consisted of $6-10$ persons. These are large household sizes with the advantage of providing labour for the farm if most members can work in the farm. The downside of a large household size with very young or very old people is that they cannot contribute to household income.

There were no illiterates in the respondent population with a majority (49\%) of the respondents having atleast primary education. The level of education is very important in farming for research has shown that educated farmers take very reasonable decisions concerning their farms [26]. The main source of income for most of the respondents (81\%) was crop farming followed by livestock farming (13\%). 96.5\% of the respondents use fuel wood as their main source of energy.

\subsection{Agroforestry practices adopted in the Mount Bamboutos}

The respondents revealed that they started practicing agroforestry in the study area since 2013, however the highest rate of adoption was observed in 2019. In 2019, ERuDeF was actively involved in sensitizing, training and providing seeds for agroforestry practices in the study area. Six major agroforestry practices (planting of fodder, fertilizer, fruit and timber trees, compost and farm yard manure) were carried out by the respondents as described in Table 2 below.

Table 2 Agroforestry Practice Status of Participants

\begin{tabular}{|c|c|c|c|}
\hline Variable & Description & Frequency & Percentage \\
\hline \multirow{6}{*}{ Type of agroforestry practice * } & Fertilizer trees & 106 & \\
\hline & Fodder trees & 70 & \\
\hline & Fruit trees & 103 & \\
\hline & Timber trees & 89 & \\
\hline & Farmyard manure & 67 & \\
\hline & Compost & 41 & \\
\hline \multirow{6}{*}{ year adopt agroforestry } & 2013 & 23 & 12 \\
\hline & 2016 & 23 & 12 \\
\hline & 2017 & 38 & 20 \\
\hline & 2018 & 28 & 14 \\
\hline & 2019 & 57 & 29 \\
\hline & 2020 & 26 & 13 \\
\hline
\end{tabular}

Fertilizer trees add nutrients to the soil through nitrogen fixing in the nodules. The main species planted in the study area was Trephosia. It is known to have both fertilizer and pesticidal properties. Fodder trees are used to feed animals. Their leaves and soft branches are harvested and fed to animals. The main species planted in the study area was Leuceana Lecophala.

Fruit trees provide food for family consumption as well as for income generation. They are a very important component of an agroforestry system. The most planted fruit tree in the study area was avocado. Timber trees are used for construction, furniture production or sold for income generation. They also provide fuel wood for the farmer. 
Farmyard and compost manures are used to improve soil fertility and in the Trans Nzoia district in Western RegionKenya several success stories from farmers have been recorded [27]. The manures were prepared from a combination of organic materials and animal wastes. Most of the respondents reared livestock and used their waste for manure production. The main livestock reared in the study area were; chicken, pigs, goats, sheep, guinea pigs, rabbits, and grass cutters.

\subsection{Adoption of agroforestry practices}

The respondents stated four main reasons why they adopted agroforestry practices (Figure 1). Most (50\%) respondents adopted agroforestry practices for better crop yields, this was followed by for diverse income (20\%), for fuel wood production (15\%) and for animal feed (14\%). With declining soil fertility, farmers try to improve soil quality and hence crop yields through agroforestry practices. Agroforestry has the ability to (1) enrich soil organic carbon better than monocropping systems, (2) improve soil nutrient availability and soil fertility due to the presence of trees in the system, and (3) enhance soil microbial dynamics, which would positively influence soil health [28]. Responses of the interviewed farmers show that farmers were indeed convinced that agro-forestry help them to replenish soil fertility and hence improved yields. This is similar to the results of detailed field and case studies carried out in Western Kenya [29]. The multipurpose function of agroforestry gives the farmer the possibility to have income from multiple sources. Almost all (96.5\%) of the respondents in the study area agreed that their main source of energy was fuel wood. Agroforestry practices help farmers to have enough fuel wood for their households. Respondents reared animals and needed to feed the animals; this justifies why fodder trees were among the major agroforestry practices in the study area.

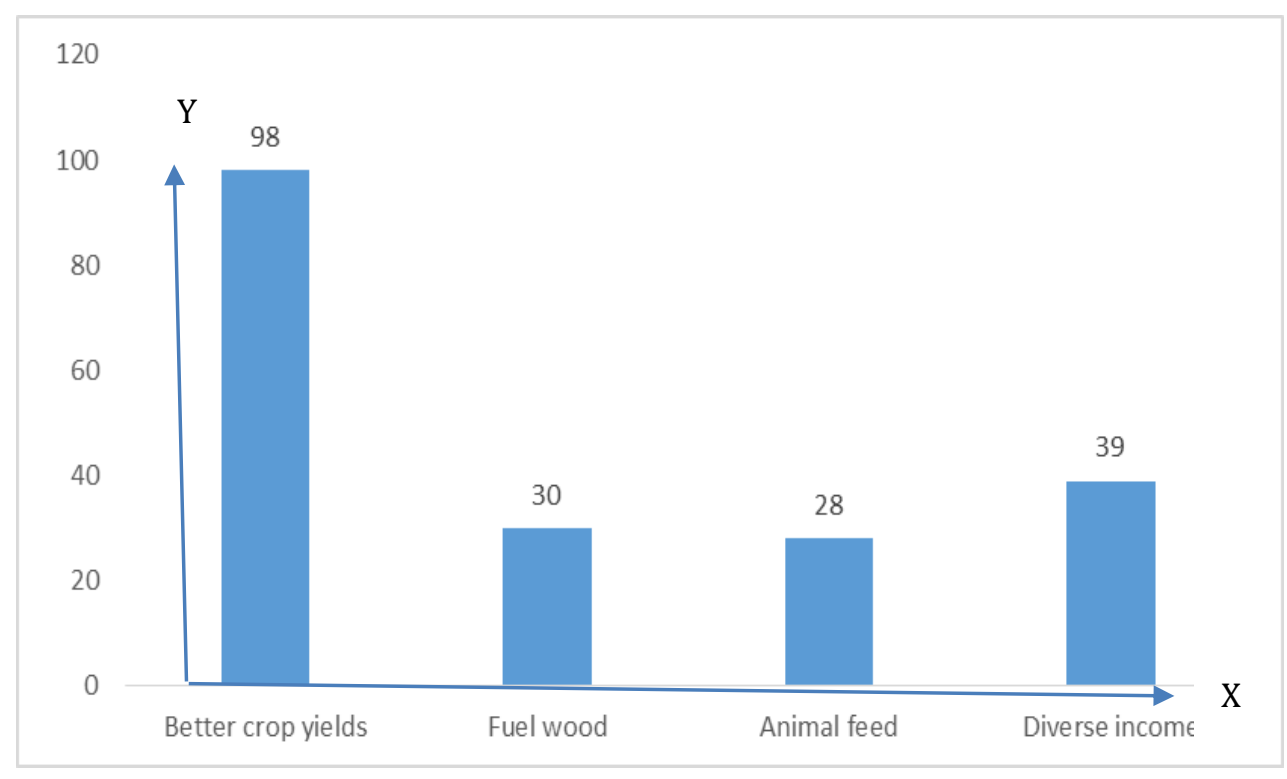

Figure 1 Reasons for agroforestry practices adoption

\subsection{Constraints to the adoption of agroforestry practices}

It was noted that the different agroforestry practices were not adopted at the same rate and this research sorted to find out the reason. Three main constraints were put forth by the respondents namely; lack of training, lack of seeds and too much labour. As presented in Figure 2 lack of training was rated as the main constraint for the adoption of agroforestry practices. Lack of seeds was rated as a second main constraint to the adoption of agroforestry practices no matter the type of agroforestry practice. As evoked by the respondents, seeds for fertilizer, fodder, fruit and timber trees were not readily available. Association between adoption of some agroforestry technologies with knowledge of the technology, availability of seed, and having the appropriate skills was found in a study among smallholder farmers in Zambia [30]. The importance of training for agroforestry adoption was evident in a study in Zimbabwe where formally trained farmers adopted agro-forestry technologies more than informally-trained farmers [31]. In Rwanda, it was found that due to lack of skills and technical know-how, capital and quality seeds, some farmers were declining to adopt the agroforestry practices [32].

Lack of knowledge and lack of seed/planting materials influence the adoption of agro-forestry [33]. Concerning the practice of manure production, labour was cited as the second constraint to its adoption. Manure production requires 
shredding of material, layering, mixing and watering. Most farmers consider the activities to be labourous and would not want to do it.

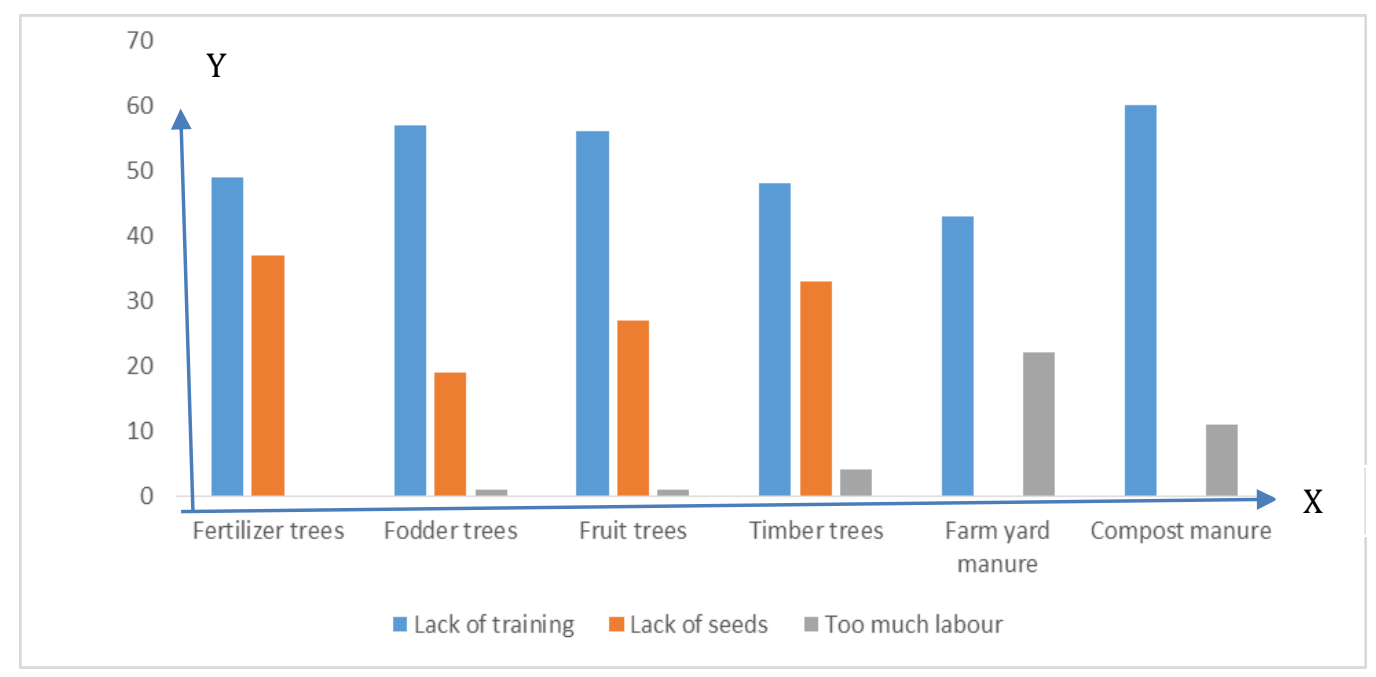

Figure 2 Constraints to the adoption of agroforestry practices

\subsection{Food security situation of the respondents}

The household food security status of the respondents is presented in Figure3. 39\% of the respondent households were food secure, while $28 \%$ were severely food insecure. Food insecure households are those that experience inadequate food intake due to lack of resources that enable them to command or produce food needed to maintain an acceptable level of consumption. They result to skipping meals, eating less and doing activities that they don't prefer in order to get food.

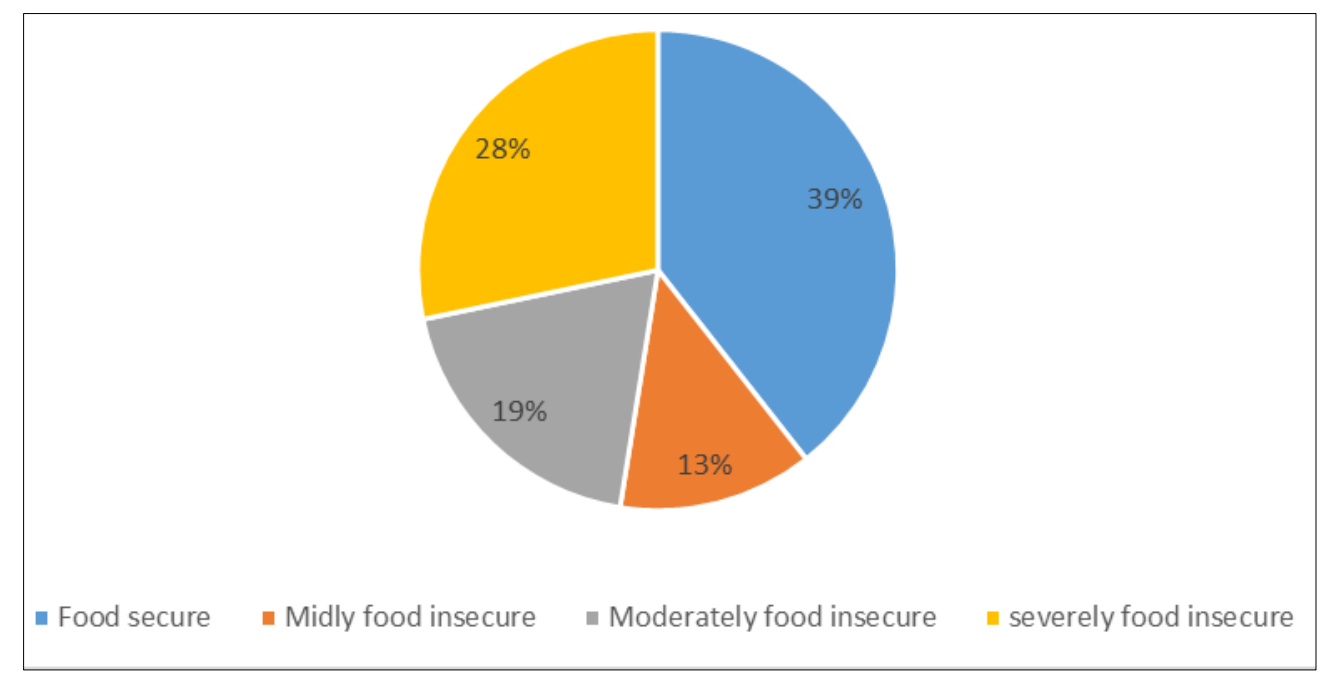

Figure 3 Household food security status in the Mount Bamboutos landscape

\subsection{Association between agroforestry practices and food security}

It was necessary to find out if practicing agroforestry was associated with household food security. A Pearson correlation which is used to find the association between two categorical variables was used. The results showed that household food security was significantly and positively associated with the planting of fodder trees, timber trees and fruit trees (Table3). These results are in agreement with a study which reported that agroforestry supports food and nutritional security through the direct provision of food, by raising farmers' incomes and providing fuel for cooking, and through various ecosystem services [34]. Other researchers have illustrated how agroforestry systems can increase 
yield while also advancing multiple sustainable development goals (SDGs), especially for the small developing-world agriculturalists central to the SDG framework. Agroforestry also increases resilience of crops and farm livelihoods, especially among the most vulnerable food producers. The adoption of agroforestry practices on farmland would greatly boast food production and soil nutrients [35]. Fertilizer trees improve food security for adopters in maize-based mixed farming systems through increased in average value of food production and maize productivity [36]. Apart from compost manure that was negatively associated with food security, all the other agroforestry practices were positively associated with food security. The negative association could be attributed to the non-mastering of the composting technique that usually results in compost of low quality that does not pay off.

Table 3 Pearson correlation between food security status and agroforestry practices

\begin{tabular}{|c|c|c|c|c|c|c|c|}
\hline Variable & $\begin{array}{l}\text { Fodder } \\
\text { trees }\end{array}$ & $\begin{array}{l}\text { Timber } \\
\text { trees }\end{array}$ & $\begin{array}{l}\text { Fertilizer } \\
\text { trees }\end{array}$ & $\begin{array}{l}\text { Fruit } \\
\text { trees }\end{array}$ & $\begin{array}{l}\text { Farm yard } \\
\text { manure }\end{array}$ & $\begin{array}{l}\text { Compost } \\
\text { manure }\end{array}$ & $\begin{array}{l}\text { Food } \\
\text { security } \\
\text { status }\end{array}$ \\
\hline Fodder trees & 1 & & & & & & \\
\hline Timber trees & $0.594^{* *}$ & 1 & & & & & \\
\hline Fertilizer trees & $0.554^{* *}$ & $0.580^{* *}$ & 1 & & & & \\
\hline Fruit trees & $0.630^{* *}$ & $0.570^{* *}$ & $0.684^{* *}$ & 1 & & & \\
\hline Farm yard manure & $0.356^{* *}$ & $0.544^{* *}$ & $0.551^{* *}$ & $0.519^{* *}$ & 1 & & \\
\hline Compost & $0.434^{* *}$ & $0.549^{* *}$ & $0.331^{* *}$ & $0.576^{* *}$ & $0.462^{* *}$ & 1 & \\
\hline Food security status & $0.240^{* *}$ & $0.284^{* *}$ & 0.002 & $0.225^{* *}$ & 0.146 & -0.014 & 1 \\
\hline
\end{tabular}

\section{Conclusion}

Most respondents were males (76\%) and were all literate with a majority using fuel wood as their main source of energy. The major agroforestry practices were, planting of fodder, fertilizer, fruit and timber trees, compost and farm yard manure preparation. The highest year of adoption of agroforestry practices was in 2019. The reasons for the adoption of agroforestry practices were; for better crop yields, fuel wood, animal feed and for diverse income. The main constraints to the adoption of agroforestry practices were lack of training, lack of seeds and much labour involved. $39 \%$ of the respondents were food secure and 28\% severely food insecure. Apart from compost manure that was negatively associated with food security, all the other agroforestry practices were positively associated with food security. It is recommended that extension agents and other stakeholders should intensify efforts to educate and train more farmers on the practice and advantages of agroforestry. This will go a long way to increase adoption rate while ensuring food security.

\section{Compliance with ethical standards}

\section{Acknowledgments}

The authors are grateful for the financial support of the Darwin Initiative and Tree Sisters. The technical support of the International Tree Foundation (ITF) and the farmers around mount Bamboutos is greatly acknowledged.

\section{Disclosure of conflict of interest}

Authors declare no conflict of interest.

\section{Statement of informed consent}

Informed consent was obtained from all individual respondents included in the study. 


\section{References}

[1] Mbow C, Noordwijk MV, Luedeling E, Neufeldt H, Minang PA, Kowero G. Agroforestry solutions to address food security and climate change challenges in Africa. Current Opinion in Environmental Sustainability. 2014; 6: 6167.

[2] Awazi NP, Tchamba NM. Enhancing agricultural sustainability and productivity under changing climate conditions through improved agroforestry practices in smallholder farming systems in sub-Saharan Africa. African Journal of Agricultural Research. 2019; 14(7): 379-388.

[3] Awazi NP, Tchamba NM, Temgoua LF. Enhancement of resilience to climate variability and change through agroforestry practices in smallholder farming systems in Cameroon. Agroforestry Systems. 2019; 88: 947-956.

[4] Leakey RRB. Definition of Agroforestry Revisited. Agroforestry Today. 1996: 8(1): 5-7.

[5] Jose S. Agroforestry for ecosystem services and environmental benefits: An overview. Agroforestry Systems. 2009; 76: 1-10.

[6] Nair PKR, Garrity D. Agroforestry - The Future of Global Land Use. Advances in Agroforestry. 2012; 9(1).

[7] Amare D, Wondie M, Mekuria W, Darr D. Agroforestry of smallholder farmers in Ethiopia: Practices and benefits. Small-scale Forestry. 2018; 18(1): 39-56.

[8] Jerneck A, Olsson L. More than trees! Understanding the agroforestry adoption gap in subsistence agriculture: Insights from narrative walks in Kenya. Journal of Rural Studies. 2013; 32: 114-125.

[9] Abubakar AS, Fondo TA, Nyong PA. Agroforestry for sustainable agriculture in the Western Highlands of Cameroon Haya: The Saudi Journal of Life Sciences. 2020; 5(9): 160-164.

[10] Kumar BM, Nair PKR. The enigma of tropical home gardens. Agroforestry System. 2004; 61: $135-152$.

[11] Kumar M, Bhatt VP, Rajwar GS. Plant and soil diversities in a sub-tropical forest of the Garhwal Himalaya. Ghana Journal of Forestry. 2006; 19-20: 1-19.

[12] Tynsong H, Tiwari BK. Plant Diversity in the Homegardens and their Significance in the Livelihoods of War Khasi Community of Meghalaya. Journal of Biodiversity. 2009; 1(1).

[13] Kebebew Z, Endale BJ, Ermias M. Analysis of socio-economic contribution of agroforestry systems to smallholder farmers around Jimma town, Southwestern Ethiopia. 2020; 12(1): 48-58.

[14] Olajide-Taiwo FB, Adeoye IB, Adebisi-Adelani O, Odeleye OMO, Fabiyi AO, Olajide-Taiwo LO. Assessment of the benefits and constraints of home gardening in the neighborhood of the National Horticultural Research Institute, Ibadan, Oyo State. American-Eurasian Journal of Agricultural and Environmental Science. 2010; 7(4): $478-483$.

[15] Bishaw B, Abdu A. Agroforestry and Community Forestry for Rehabilitation of Degraded Watersheds on the Ethiopian Highlands. International Conference on Development Studies in Ethiopia. 2003.

[16] Krishnal S, Weerahewa J, Gunaratne LHP. Role of Home gardens in Achieving Food Security in Batticaloa District, Sri Lanka. International Conference on Economics and Finance Research IPEDR. 2012; 32.

[17] Ndaeyo NU. Assessing the contributions of homestead farming to food security in a developing economy: A case study of southeastern Nigeria (University of Uyo (Nigeria). Dept. of Crop Science. Journal of Agriculture and Social Sciences (Pakistan). 2007; 1813-2235.

[18] Lulandala LL. Meeting the Needs of the People Through Species Domestication: A Basis for Effective Conservation of the Eastern Arc Mountain Forest Biodiversity. Journal of East African Natural History. 2009; 87: $243-252$.

[19] Musotsi A, Asenath S, Onyango MOA. The role of home gardening in household food security in Butere Division of western Kenya. African Journal of Food, Agriculture, Nutrition and Development. 2008; 8(4): 375-391.

[20] Akinnifesi FK, Ajayi OC, Sileshi G, Chirwa P, Chianu J. Fertilizer trees for sustainable food security in the maizebased production systems of East and Southern Africa region: a review. Agronomy for Sustainable Development. 2010; 30: 615-629.

[21] Kalaba FK, Paxie C, Heidi, P. The contribution of indigenous fruit trees in sustaining rural livelihoods and conservation of natural resources. Journal of Horticulture and Forestry. 2009; 1(1): 001-006. 
[22] Tematio P, Kengni L, Bitom D, Hodson M, Fopoussi JC, Leumbe O, Mpakam HG, Tsozué D. Soils and their distribution on Bambouto volcanic mountain, West Cameroon highland, Central Africa. Journal of African Earth Sciences. 2004; 39: 447-457.

[23] Coates J, Swindale A, Bilinsky P. Household Food Insecurity Access Scale (HFIAS) for measurement of Household Food Access: Indicator GUIDE (V.3), Washington, D.C., FHI 360 FANTA. 2007.

[24] FAO. The Role of Women in Agriculture ESA Working Paper No. 11-02. 2011.

[25] Fortmann L, Rocheleau D. Women and agroforestry: four myths and three case studies Agroforestry Systems. $1985 ; 2: 253-272$.

[26] FAO. The economic lives of smallholder farmers: An analysis based on household data from nine countries. 2015.

[27] Nekesa AO, Okalebo JR, Kimetto S. Adoption of Leguminous Trees/Shrubs, Compost and Farmyard Manure(FYM) As Alternatives to Improving Soil Fertility in Trans NzoiaDistrict-Kenya. A. Bationo (eds.), Advances in Integrated Soil Fertility Management in Sub-Saharan Africa: Challenges and Opportunities. 2007; 955-960.

[28] Dollinger J, Shibu J. Agroforestry for soil health. Agroforestry System. 2018; 92: 213-219.

[29] Mango N, Hebinck P. Agroforestry: A second soil fertility paradigm? A case of soil fertility management in Western Kenya. Cogent Social Sciences. 2016; 2(1): 1215779.

[30] Kabwe G, Bigsby H, Cullen R. Factors influencing adoption of agroforestry among smallholder farmers in Zambia. Paper presented at the 2009 NZARES Conference. Tahuna Conference Centre - Nelson, New Zealand. August 2728, 2009.

[31] Parwada C, Gadzirayi CT, Muriritirwa WT, Mwenye D. Adoption of agro-forestry technologies among smallholder farmers: A case of Zimbabwe. Journal of Development and Agricultural Economics. 2010; 2(10): 351-358.

[32] Pilote K, Jewel A, Yohan L, Don KL. Benefits and challenges of agroforestry adoption: a case of Musebeya sector, Nyamagabe District in southern province of Rwanda.Forest Science and Technology. 2017; 13(4) 174-180.

[33] Jamala GY, Shehu HE, Yidau JJ, Joel L. Factors Influencing Adoption of Agro-Forestry among Smallholder Farmers in Toungo, Southeastern, Adamawa State, Nigeria. IOSR Journal Of Environmental Science, Toxicology And Food Technology (IOSR-JESTFT). 2013; 6(36): 66-72.

[34] Ian KD, Frank P, Torquebiau E, Malézieux E, Miyuki I, Gudeta WS, Katja K, Eliot M, Stepha M, Ramni J. Agroforestry, food and nutritional security. Background paper for the International Conference on Forests for Food Security and Nutrition, FAO, Rome, 13-15 May, 2013.

[35] Waldron A, Garrity D, Malhi Y, Girardin C, Miller DC, Seddon N. Agroforestry can enhance food security while meeting other sustainable development goals. Special Issue: Commercial Agriculture in Tropical Environments. Tropical Conservation Science. 2017; 10: 1-6.

[36] Coulibaly JY, Chiputwa B, Nakelse T, Kundhlande G. Adoption of Agroforestry and its impact on household food security among farmers in Malawi. ICRAF. 2016; 223. 